АСАУЛЕНКО І.О., ст. гр. 4-V-T,

ЖУЧЕНКО О.С., к.т.Н., доцент,

ПРИХОДЬКО С.І., д.т.н., професор,

ШТОМПЕЛЬ М.А., к.т.н., доцент (УкрДУЗТ)

\title{
Дослідження характеристик методу декодування кодів 3 малою щільністю перевірок на парність на основі стохастичної оптимізації
}

Розглянуто основні етапи методу декодування кодів з малою щүільністю перевірок на парність на основі стохастичної оптимізації, сутність якого полягає у знаходженні максимального значення иільоової функиії з використанням популяційних процедур пошукової оптимізаџії. Обтрунтовано доцільність застосовування у якості пошукового механізму популяційної процедури, натхненної летучими мишами. Наведені припущення, основні кроки та математична модель даної популяційної процедури. Показано, шчо запропонований метод декодування кодів з малою шільністю перевірок перевершує класичний метод жорсткого декодування на основі інвертування біта за енергетичною ефективністю та має прийнятну обчислювальну складність.

Ключові слова: декодування, коди з малою щүільністю перевірок на парність, иэільова функиія, популяційні прочедури.

\begin{abstract}
Постановка проблеми і аналіз літератури
Класичними методами декодування кодів з малою щільністю перевірок на парність $є$ метод жорсткого декодування на основі інвертування біта та метод м'якого декодування на основі розповсюдження довіри, що мають ряд обмежень та не задовольняють вимогам сучасних телекомунікаційних технологій і стандартів [1, 2]. У [3, 4] запропоновано метод декодування кодів 3 малою щільністю перевірок на парність на основі стохастичної оптимізації, що заснований на обчисленні значення відповідної цільової функції 3 використанням узагальнених популяційних процедур пошукової оптимізації. При цьому актуальною задачею являється дослідження характеристик запропонованого методу декодування кодів з малою щільністю перевірок на парність при застосуванні популяційних процедур деякого класу.
\end{abstract}

\section{Мета статті}

Дослідження характеристик методу декодування кодів 3 малою щільністю перевірок на парність на основі стохастичної оптимізації.

\section{Основна частина}

Нехай $H$ позначає перевірочну матрицю коду з малою щільністю перевірок на парність розмірністю $m \times n$, де $n>m \geq 1$, тоді даний код $C$ можна визначити як $C \equiv\left\{\bar{c} \in F_{2}^{n}: H c=0\right\}$, де $F_{2}^{n}$ означає двійкове поле Галуа. При цьому передбачається, що вектор $\bar{c} \epsilon$ вектором-стовпцем. Введемо біполярний код з малою щільністю перевірок на парність $\widetilde{C}$, що відповідає коду $C$, та визначається як $\widetilde{C} \equiv\left\{\left(b_{1}=1-2 c_{1}, b_{2}=1-2 c_{2}, \ldots, b_{n}=1-2 c_{n}\right): \bar{c} \in C\right\}$. Таким чином, $\widetilde{C} \in$ підмножиною $\{+1 ;-1\}^{n}$, що отримується $3 C$ шляхом відображення двійкових символів $(0,1)$ у біполярні символи $(+1,-1)$.

Припускається, що використовується канал 3 двійковим входом та адитивним білим гаусовим шумом (АБГШ), що визначається як $\bar{y}=\bar{b}+\bar{z}(\bar{b} \in \tilde{C})$. При цьому вектор $\bar{z}=\left(z_{1}, \ldots, z_{n}\right) \in$ вектором білого гаусового шуму, а $z_{j}(j \in[1, n]) \quad \epsilon \quad$ гаусовою випадковою величиною 3 нульовим математичним очікуванням та дисперсією $\sigma^{2}$.

Нехай бітові вершини $N(i)$ і перевірочні вершини $M(j)$ графу Таннера, де $(i \in[1, m], j \in[1, n])$, визначаються як $N(i) \equiv\left\{j \in[1, n]: h_{i j}=1\right\} \quad$ i $M(j) \equiv\left\{i \in[1, m]: h_{i j}=1\right\}$, де $h_{i j} \in \quad i j$-елементом перевірочної матриці $H$. Виходячи 3 цього, перевірочну умову для деякого прийнятого вектору $\bar{x}$ у випадку біполярних кодів можна представити як $\prod_{j \in N(i)} x_{j}=1(\forall i \in[1, m]), \quad$ що еквівалентно $\bar{x}=\left(x_{1}, \ldots, x_{n}\right) \in \tilde{C}$. В даному випадку, значення $\prod_{j \in N(i)} x_{j} \in\{+1,-1\} \quad$ називають $i$-ою складовою біполярного синдрому вектору $\bar{x}$. (ㄱ І.О. Асауленко, О.С. Жученко, С.І. Приходько, М.А. Штомпель, 2016 
У $[4,5]$ показано, що процес декодування кодів 3 малою щільністю перевірок на парність доцільно здійснювати з використанням цільової функції

$$
f(\bar{x})=\sum_{j=1}^{n} x_{j} y_{j}+\sum_{i=1}^{m} \prod_{j \in N(i)} x_{j}
$$

У цільовій функції (1) перший доданок відповідає кореляції між біполярним кодовим словом і прийнятим словом, який повинен набувати максимального значення, а другий доданок $\epsilon$ сумою складових біполярного синдрому вектору $\bar{x}$. При цьому другий доданок приймає максимальне значення $\sum_{i=1}^{m} \prod_{j \in N(i)} x_{j}=m$, тільки якщо $\bar{x} \in \tilde{C}$. Таким чином, дану складову можна розглядати як штраф (штрафну функцію), який змушує $\bar{x}$ відповідати дійсному кодовому слову.

У загальному випадку основні етапи методу декодування кодів 3 малою щільністю перевірок на парність на основі стохастичної оптимізації наведені нижче.

Етап 1. Нехай $x_{j}=\operatorname{sign}\left(y_{j}\right)$, де $x_{j}=+1$, якщо $y_{j} \geq 0$, та $x_{j}=-1$ - в іншому випадку; для $j \in[1, n]$. В результаті отримаємо вектор $\bar{x}=\left(x_{1}, x_{2}, \ldots, x_{n}\right)$.

Етап 2. Якщо перевірочна умова $\prod_{j \in N(i)} x_{j}=+1$ виконується для всіх $i \in[1, m]$, то вектор $\bar{x}$ є кодовим словом та процес декодування завершується.

Етап 3. Пошук 3 використанням популяційних процедур пошукової оптимізації вектору $\bar{x}$, що забезпечує максимальне значення цільової функції (1).

Етап 4. Якщо число ітерацій менше максимального числа ітерацій $L_{\max }$, тоді повертаємося до етапу 3 , в іншому випадку - поточний вектор $\bar{x} \epsilon$ кодовим словом та процес декодування завершується.

Отже, у процесі декодування згідно даного методу спочатку виконується жорстке рішення на основі прийнятого вектору $\bar{y}$, в результаті якого формується біполярний вектор $\bar{x}$. Якщо перевірочна умова задовольняється для кожного елементу вектору $\bar{x}$, то приймається рішення, що даний вектор $є$ кодовим словом та процес декодування завершується. В противному випадку здійснюється пошук біполярного вектору $\bar{x}$ з використанням популяційних методів до досягнення максимального числа ітерацій $L_{\max }$. Пошук завершується формуванням вектору $\bar{x}$, що забезпечує максимальне значення цільової функції (1) та приймається у якості переданого кодового слова.
Згідно даного методу декодування кодів 3 малою щільністю перевірок на парність на етапі 3 можна використовувати популяційні процедури пошукової оптимізації різних класів: еволюційні процедури; популяційні процедури, натхненні живою природою; процедури, натхненні неживою природою; процедури, натхненні людським суспільством тощо. У [7] показано, що популяційна процедура, що натхненна поведінкою летучих мишей, є більш ефективною, ніж процедура еволюційного пошуку чи процедура рою частинок. Тому розглянемо можливість використання даної популяційної процедури на етапі 3 запропонованого методу декодування кодів 3 малою щільністю перевірок на парність.

Популяційна процедура, натхненна летучими мишами, заснована на таких припущеннях. Летучі миші рухаються випадковим чином. Поточне положення і швидкість миші $s_{k}, k \in[1:|S|]$, де $|S|-$ розмірність поточної популяції, дорівнюють $X_{k}$ i $V_{k}$ відповідно. Для пошуку здобичі летучі миші генерують сигнали з частотою $\sigma_{k}$ та гучністю $a_{k}$. В процесі пошуку миші можуть змінювати частоту цих сигналів, а також частоту повторення випромінюваних імпульсів $r_{k}$. Частота сигналів може змінюватися в діапазоні $\left[\varpi^{\min } ; \varpi^{\max }\right], \quad \sigma^{\max }>\varpi^{\min } \geq 0$, гучність сигналу - в межах $[0 ; 2]$ та частота повторення випромінюваних імпульсів - в межах $[0 ; 1]$.

У разі максимізації фітнес-функції $\varphi(\bar{x})$, що відповідає цільовій функції (1), основні кроки популяційної процедури, натхненної летучими мишами, мають наступний вигляд.

Крок 1. Ініціалізація популяції. Задаємо початкові положення агентів $s_{k}, k \in[1:|S|]$. Визначаємо глобально кращого агенту i відповідне йому рішення $\bar{x}^{*}$.

Крок 2. Міграція агентів. Виконуємо переміщення всіх агентів на один крок у відповідності 3 використовуваною міграційною процедурою.

Крок 3. Локальний пошук. 3 ймовірністю $\boldsymbol{\xi}_{k}^{r}$ (вільний параметр процедури) реалізуємо процедуру локального пошуку в околиці кращого рішення $\bar{x}_{k}^{*}$, знайденого агентом $s_{k}$ за всі попередні ітерації. Приймаємо знайдене рішення в якості нового поточного положення агенту $s_{k}, k \in[1:|S|]$.

Крок 4. Глобальний пошук. В околиці поточного рішення $\bar{x}_{k}$ випадковим чином генеруємо рішення $\bar{x}_{k}^{\prime}$. Якщо $\varphi\left(\bar{x}_{k}^{\prime}\right)>\varphi\left(\bar{x}^{*}\right), \quad$ то 3 ймовірністю $\xi_{k}^{a}$ 
приймаємо рішення $\bar{x}_{k}^{\prime}$ в якості нового поточного положення агенту $\boldsymbol{s}_{k}$ Знаходимо нове глобально краще рішення $\bar{x}^{*}$.

Крок 5. Еволюція параметрів $\xi_{k}^{r}, \xi_{k}^{a} ; k \in[1:|S|]$.

Крок 6. Закінчення ітерацій. Перевіряємо виконання умов закінчення ітерацій. Якщо ці умови виконані, приймаємо в якості рішення поточну точку $\bar{x}^{*}$ і завершуємо обчислення, в противному випадку повертаємося до кроку 2.

Ініціалізацію популяції здійснюємо шляхом випадкового рівномірного розподілу агентів $s_{k}, k \in[1:|S|] \quad$ в розглядуваній області простору пошуку. На цьому ж етапі задаємо початкові значення частот $\varpi_{k}$, гучності $a_{k}$ і частот повторення імпульсів $r_{k}$, рівномірного випадкового розподілу їх $\mathrm{y}$ відповідних інтервалах $\left[\varpi^{\min } ; \varpi^{\max }\right],[0 ; 2],[0 ; 1]$.

Міграцію агентів $s_{k}, k \in[1:|S|] \quad$ здійснюємо за формулами:

$\bar{x}_{k}^{\prime}=\bar{x}_{k}+V_{k}^{\prime}$,

$V_{k}^{\prime}=V_{k}+{\varpi_{k}^{\prime}}^{\prime}\left(\bar{x}_{k}-\bar{x}^{*}\right)$,

$\varpi_{k}^{\prime}=\varpi^{\min }+\left(\varpi^{\max }-\varpi^{\min }\right) U_{1}(0 ; 1)$,

де $U_{1}(0 ; 1)$ - незалежне дійсне випадкове число, що розподілене за рівномірним законом в інтервалі $[0 ; 1]$.

При цьому глобально краще рішення $\bar{x}^{*}$ визначає вираз

$\max _{k \in[1: S \mid]} \varphi\left(\bar{x}_{k}\right)=\varphi\left(\bar{x}^{*}\right)=\varphi^{*}$.

Іншими словами, у відповідності 3 міграційною процедурою агент переміщується у напрямку, що визначається сумою вектору переміщення на попередній ітерації (доданок $V_{k}$ у (2)) і випадковим чином обуреного вектору направлення на кращого агенту $\left(\bar{x}_{k}-\bar{x}^{*}\right)$.

Для здійснення локального пошуку випадковим чином варіюємо поточне положення агенту $s_{k}$ у відповідності з формулою

$\bar{x}_{k}^{\prime}=\bar{x}_{k}+\bar{a} U_{|X|}(-1 ; 1), k \in[1:|S|]$,

де $U_{|X|}(-1 ; 1)-$ вектор незалежних дійсних випадкових чисел, рівномірно розподілених в інтервалі $[-1 ; 1]$; $\bar{a}$ - поточне середнє значення гучності всіх агентів популяції

$\bar{a}=\frac{1}{|S|} \sum_{k=1}^{|S|} a_{k}$.

Далі розраховуємо значення фітнес-функції у новій точці $\varphi\left(\bar{x}_{k}^{\prime}\right)=\varphi_{k}^{\prime}$. Якщо $\varphi_{k}^{\prime}>\varphi_{k}$, то завершуємо процедуру локального пошуку, в противному випадку фіксоване число разів повертаємося до кроку 1.

Еволюцію параметрів $\xi_{k}^{a}, \xi_{k}^{r}$ з часом $t$ виконуємо за правилом:

$\xi_{k}^{a}(t+1)=b_{a} \xi_{k}^{a}(t)$,

$\xi_{k}^{r}(t+1)=\xi_{k}^{r}(0)\left(1-\exp \left(-b_{r} t\right)\right)$,

$k \in[1:|S|]$,

де $b_{a} \in(0 ; 1), \quad b_{r}>0$ - задані константи (вільні параметри процедури).

Таким чином, мають місце граничні співвідношення

$\xi_{k}^{a}(t) \underset{t \rightarrow \infty}{\longrightarrow} 0, \xi_{k}^{r}(t) \underset{t \rightarrow \infty}{\longrightarrow} \xi_{k}^{r}(0)$

Для дослідження ефективності методу декодування на основі популяційної процедури, натхненної летучими мишами, розроблено відповідні обчислювальні алгоритми та програмну реалізацію телекомунікаційної системи, що використовує коди 3 малою щільністю перевірок на парність 3 перевірочними матрицями різної розмірності.

Порівняння результатів моделювання запропонованого методу декодування та класичних методів декодування $(20,10)$ коду з малою щільністю перевірок на парність у каналі з АБГШ наведено на рис. 1.

Порівняння результатів моделювання запропонованого методу декодування та класичних методів декодування $(40,20)$ коду 3 малою щільністю перевірок на парність у каналі з АБГШ наведено на рис. 2.

Порівняння результатів моделювання запропонованого методу декодування та класичних методів декодування $(60,30)$ коду з малою щільністю перевірок на парність у каналі з АБГШ наведено на рис. 3. 


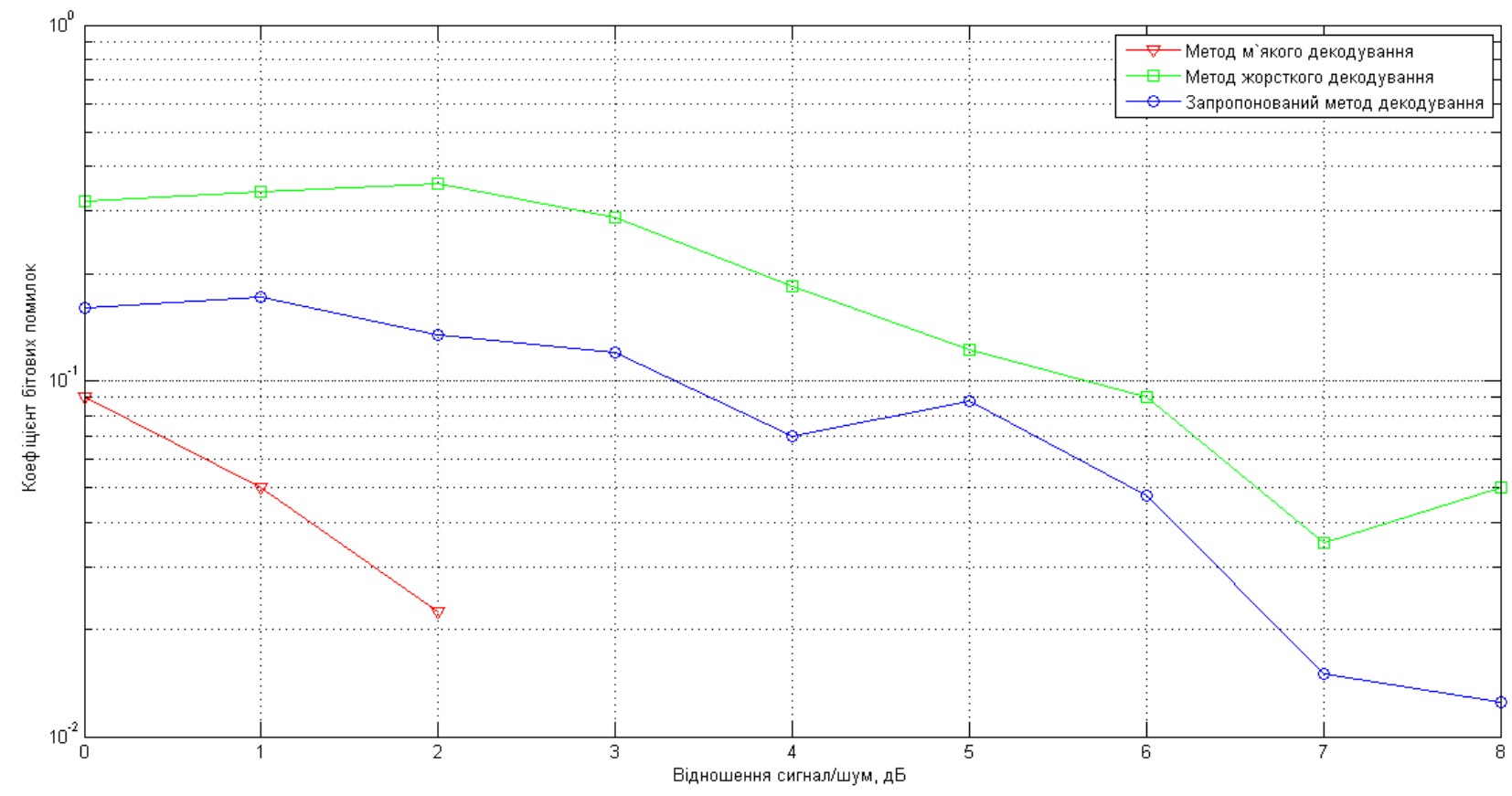

a)

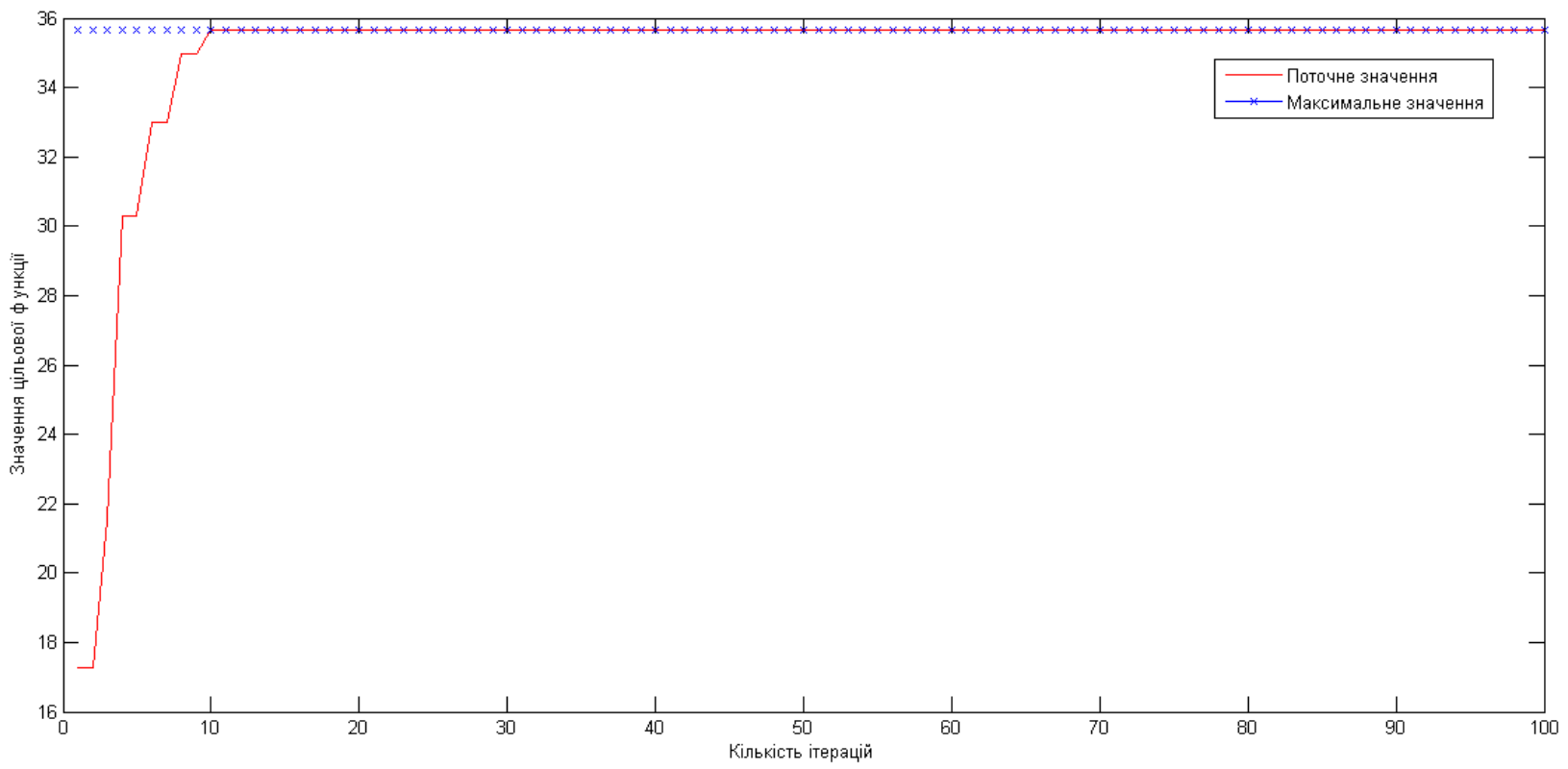

б)

Рис. 1. Результати моделювання для $(20,10)$ коду з малою щільністю перевірок на парність: а) - залежність коефіцієнту бітових помилок від відношення сигнал/шум;

б) - збіжність алгоритму, що реалізує запропонований метод декодування, при відношенні сигнал/шум 4 дБ 


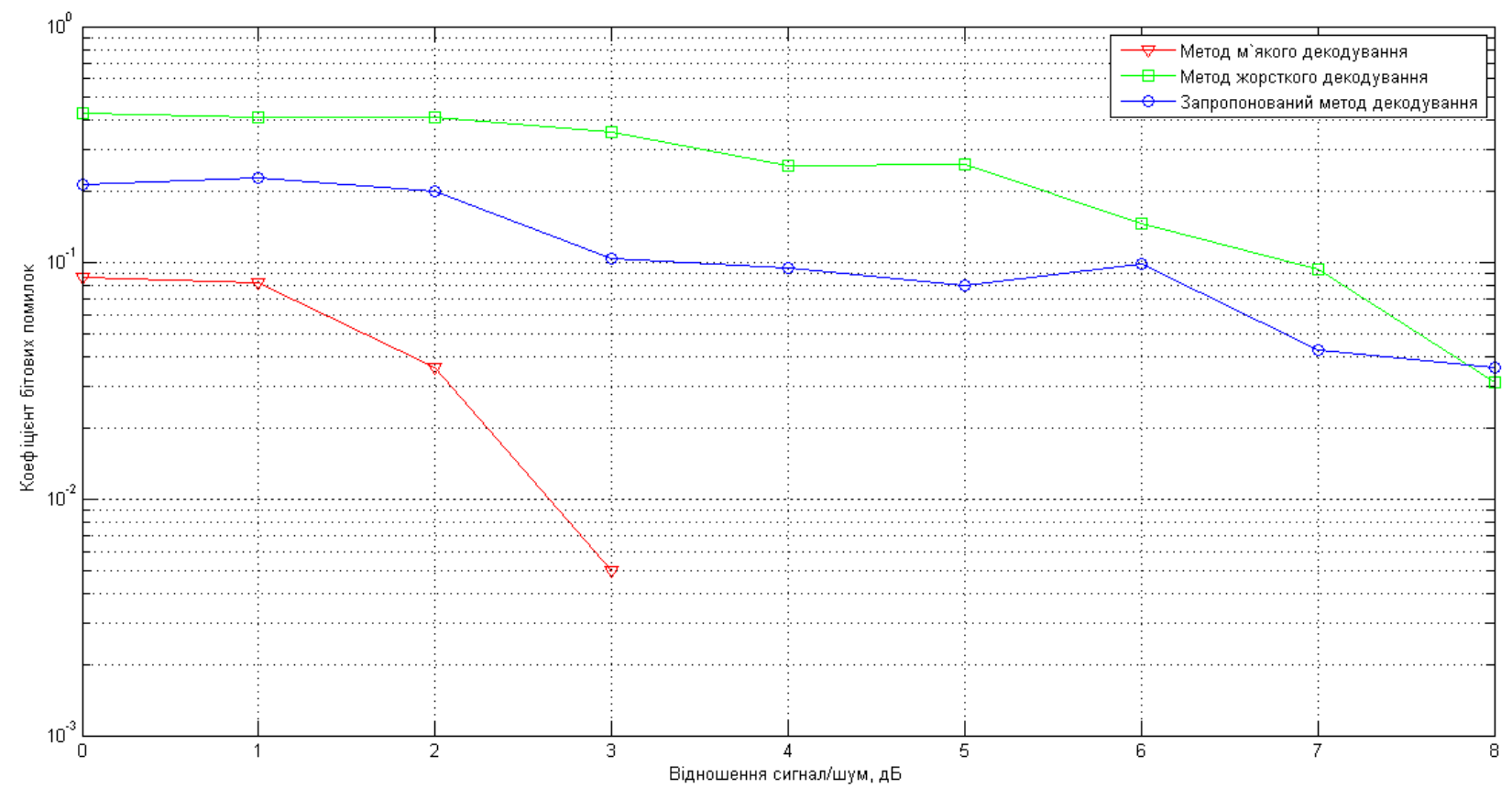

a)

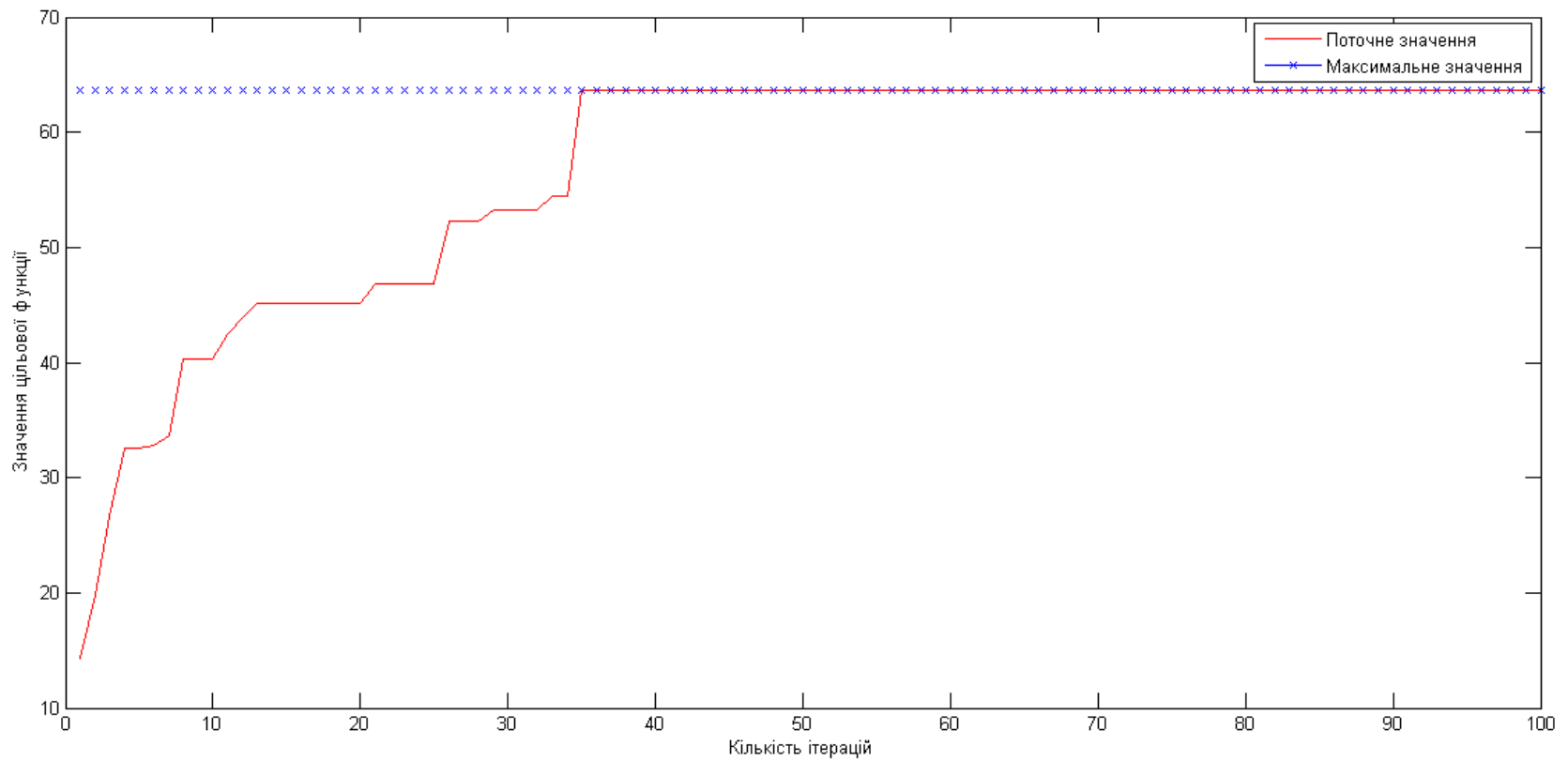

б)

Рис. 2. Результати моделювання для $(40,20)$ коду з малою щільністю перевірок на парність: а) - залежність коефіцієнту бітових помилок від відношення сигнал/шум;

б) - збіжність алгоритму, що реалізує запропонований метод декодування, при відношенні сигнал/шум 4 дБ 


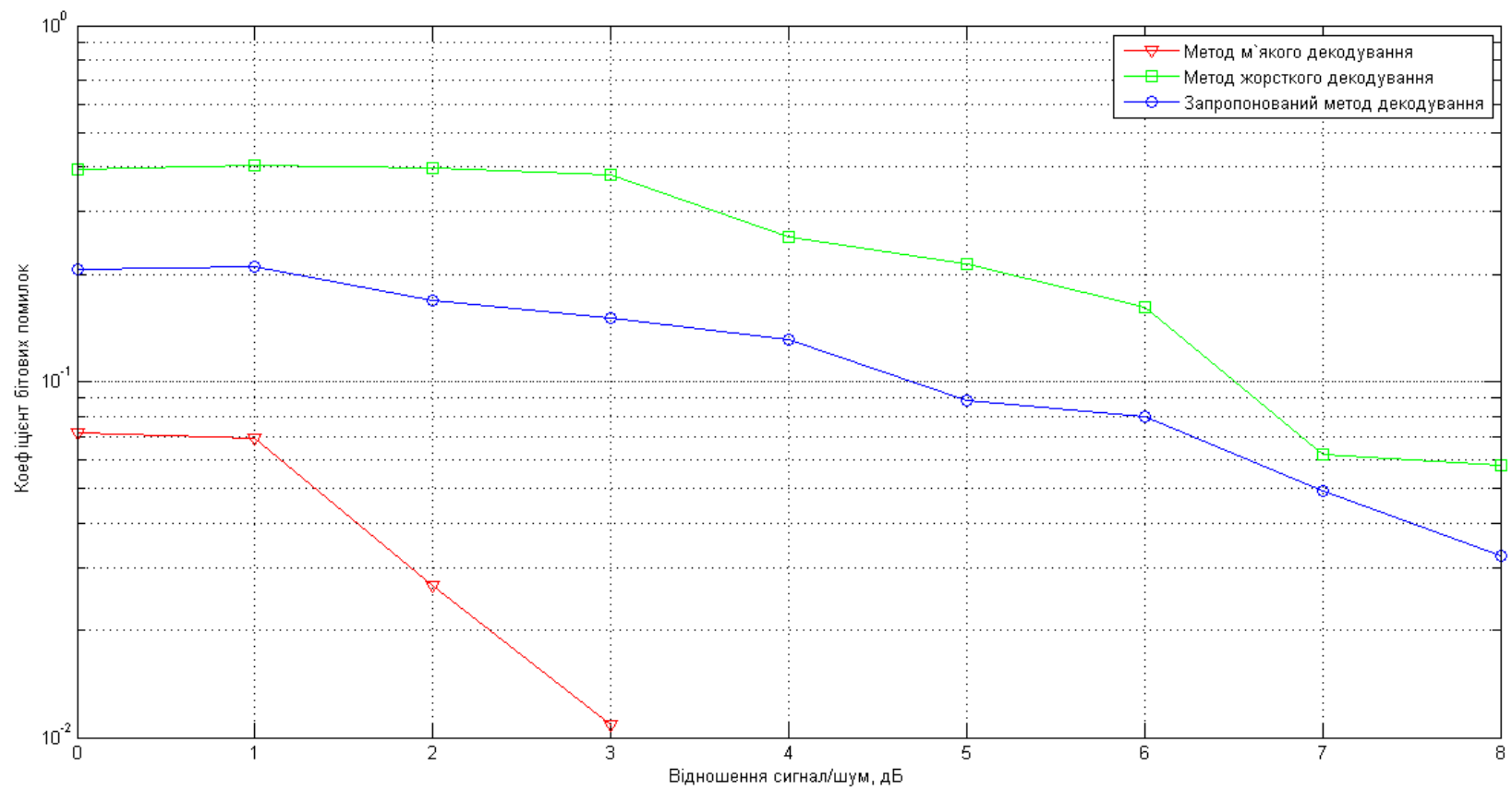

a)

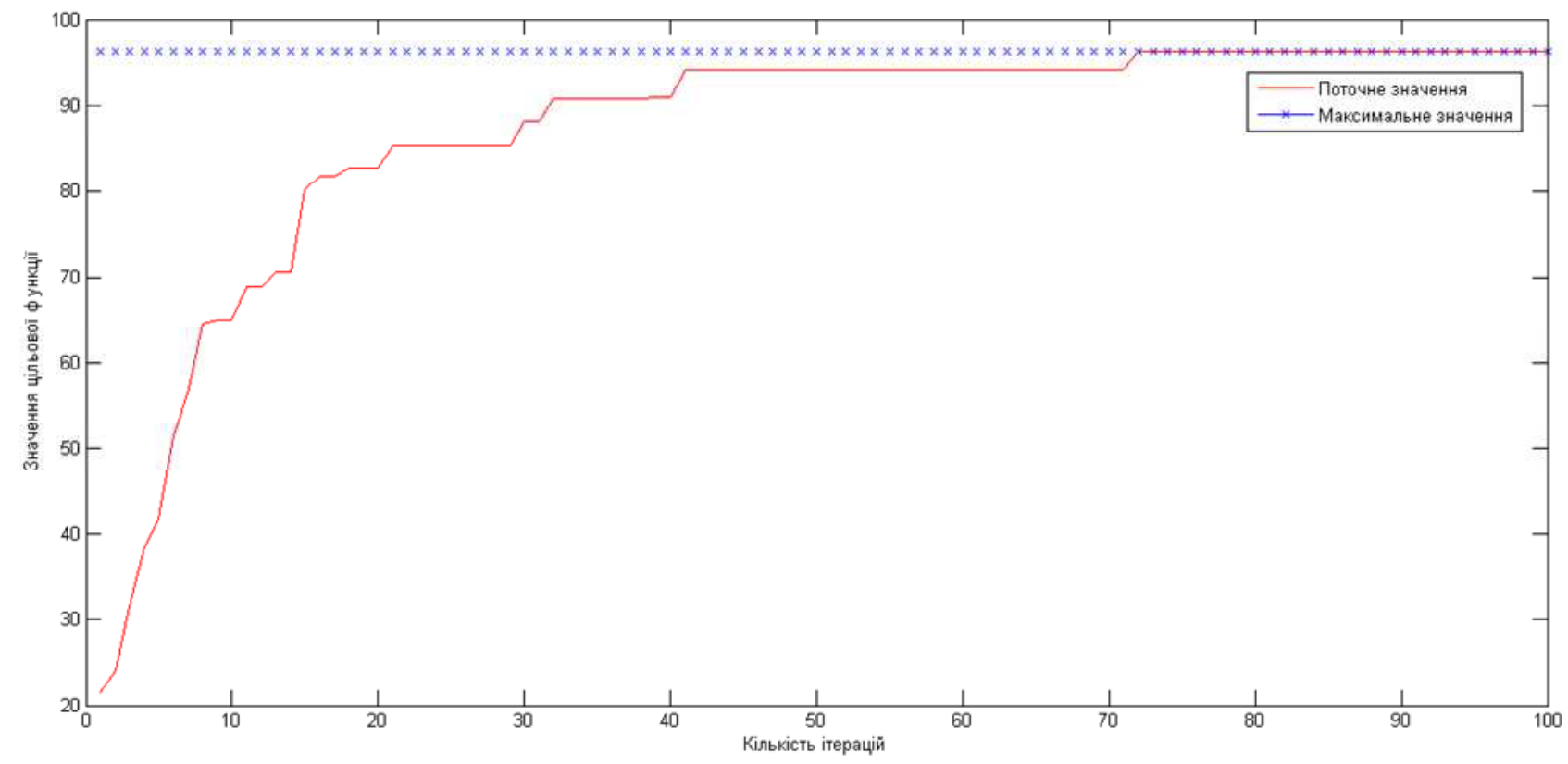

б)

Рис. 3. Результати моделювання для $(60,30)$ коду з малою щільністю перевірок на парність: а) - залежність коефіцієнту бітових помилок від відношення сигнал/шум;

б) - збіжність алгоритму, що реалізує запропонований метод декодування, при відношенні сигнал/шум 4 дБ 
3 аналізу рис. 1 - 3 випливає, що запропонований метод декодування кодів 3 малою щільністю перевірок на парність забезпечує менше значення коефіцієнту бітових помилок, ніж класичний метод жорсткого декодування на основі інвертування біта, але уступає за цим параметром класичному методу м'якого декодування на основі розповсюдження довіри. Крім того $з$ рис. 1 - 3 слідує, що необхідна кількість ітерацій запропонованого методу декодування зростає при збільшенні розмірності перевірочної матриці кодів 3 малою щільністю перевірок на парність.

\begin{tabular}{l}
\hline Висновки \\
\hline Розглянуто особливості та основні етапи методу \\
декодування кодів 3 малою щільністю перевірок на \\
парність на основі стохастичної оптимізації, що \\
заснований на знаходженні максимального значення \\
цільової функції 3 використанням популяційних \\
процедур пошукової оптимізації. Показано, що у \\
якості пошукового механізму доцільно застосовувати \\
популяційну процедуру, натхненну летучими мишами. \\
Наведені припущення, основні кроки та математична \\
модель даної популяційної процедури. 3 проведеного \\
дослідження характеристик запропонованого методу \\
декодування кодів 3 малою щільністю перевірок \\
слідує, що він перевершує класичний метод жорсткого \\
декодування на основі інвертування біта за \\
енергетичною ефективністю та має прийнятну \\
обчислювальну складність.
\end{tabular}

\section{Література}

1. Штомпель, Н. А. Методы мягкого декодирования кодов с малой плотностью проверок на четность [Текст] / Н. А. Штомпель // Вісник Національного технічного університету «Харківський політехнічний інститут»: збірник наукових праць. - 2013. - № 27 (1000). - C. 163 - 168.

2. Штомпель, Н. А. Вычислительная сложность методов декодирования кодов с малой плотностью проверок на четность [Текст] / Н. А. Штомпель // Системи обробки інформації: збірник наукових праць. - Харків: ХУПС ім. І. Кожедуба, 2013. Вип. 6 (113). - С. 177 - 180.

3. Асауленко, И.А. Метод итеративного декодирования линейных блоковых кодов на основе стохастической оптимизации [Текст] / И.А. Асауленко, С.И. Приходько, Н.А. Штомпель // Матеріали стендових доповідей та виступів учасників 28-ої міжнародної науково-практичної конференції «Інформаційно-керуючі системи на залізничному транспорті» (м. Харків, 24 - 25 вересня 2015 р.). - Інформаційно-керуючі системи на залізничному транспорті: науково-технічний журнал. Додаток. - Харків: УкрДУЗТ, 2015. - Вип. 4 (113). - С. $27-28$.
4. Асауленко, І. О. Метод декодування кодів з малою щільністю перевірок на парність на основі стохастичної оптимізації [Текст] / І. О. Асауленко, С. І. Приходько, М. А. Штомпель // Інформаційнокеруючі системи на залізничному транспорті: науково-технічний журнал. - Харків: УкрдУЗТ, 2015. - Вип. 5 (114). - С. 61 - 65.

5. Wadayama, T. Gradient descent bit flipping algorithms for decoding LDPC codes / T. Wadayama, K. Nakamura, M. Yagita, Y. Funahashi, S. Usami, I. Takumi // IEEE Transactions on Communications. 2010. - Vol. 58, № 6. - June. - P. 1610 - 1614.

6. Карпенко, А. П. Современные алгоритмы поисковой оптимизации. Алгоритмы, вдохновленные природой [Текст]: учебное пособие / А.П. Карпенко. - Москва: издательство МГТУ им. Н. Э. Баумана, 2014. - 446 с.

Асауленко И.А., Жученко А.С., Приходько С.И., Штомпель Н.А. Исследование характеристик метода декодирования кодов с малой плотностью проверок на четность на основе стохастической оптимизации. Рассмотрены основные этапы метода декодирования кодов с малой плотностью проверок на четность на основе стохастической оптимизации, сущность которого заключается в нахождении максимального значения целевой функции с использованием популяционных процедур поисковой оптимизации. Обоснована целесообразность применения в качестве поискового механизма популяционной процедуры, вдохновленной летучими мышами. Приведены предположения, основные шаги и математическая модель данной популяционной процедуры. Показано, что предложенный метод декодирования кодов с малой плотностью проверок превосходит классический метод жесткого декодирования на основе инвертирования бита по энергетической эффективности и имеет приемлемую вычислительную сложность.

Ключевые слова: декодирование, коды с малой плотностью проверок на четность, целевая функция, популяционные процедуры.

Asaulenko I., Zhuchenko O., Prihodko S., Shtompel M. Research of characteristics of decoding method of low density even parity check codes based on stochastic optimization. It is shown that the classical methods of decoding low density even parity check codes have limitations and do not satisfy the requirements of modern telecommunication technologies and standards. Basic information about bipolar low density even parity check codes is presented. It is shown, that to decode these codes, an objective function of a special kind should be used. The 
main stages of the method of decoding low density even parity check codes based on stochastic optimization, the essence of which is to find the maximum value of the objective function using a population procedures of search optimization have been considered. The expediency of the use of a population procedure, inspired by bats, as a search engine has been grounded. Assumptions, basic steps and a mathematical model of this population procedure have been given. The comparison of simulation results of the proposed decoding method and classical method of decoding low density even parity check codes with parity check matrix of different dimensions have been presented. It is shown that the method of decoding a low density even parity check codes based on stochastic optimization method is superior to classic method of hard decoding based on inversion of bit energy efficiency and has a reasonable computational complexity.

Key words: decoding, low density even parity checks codes, objective function, population procedures.

Рецензент д.т.н., професор Краснобаєв В.А. (ХНУ ім. Каразіна)

Поступила 16.12.20152.

Асауленко Ірина Олександрівна, студентка групи 4-V-T, Український державний університет залізничного транспорту, Харків, Украӥна. E-mail - asaulenkoirina@mail.ru.

Жученко Олександр Серхійович, кандидат технічних наук, дочент, доцент кафедри транспортного зв'язку, Украӥнський державний університет залізничного транспорту, Харків, Украӥна.

Приходько Сергій Іванович, доктор технічних наук, професор, проректор з науково-педагогічної роботи, Украйнський державний університет залізничного транспорту, Харків, Украӥна. E-mail-xiittc@таil.ru.

Штомпель Микола Анатолійович, кандидат технічних наук, доцент, доцент кафедри транспортного зв'язку, Украӥнський державний університет залізничного транспорту, Харків, Украӥна. E-mail - $\underline{\text { nik- }}$ shtompel@yandex.ru.

Asaulenko I.A., student, Ukrainian State University of Railway Transport, Kharkiv, Ukraine.

Zhuchenko O.S., Candidate of Techn. Sciences, docent of "Transport connection" Department, Ukrainian State University of Railway Transport, Kharkiv, Ukraine.

Prihodko S.I., Vice-rector for scientific and pedagogical work of Ukrainian State University of Railway Transport, Doctor of Technical Sciences, professor, Ukrainian State University of Railway Transport, Kharkiv, Ukraine.

Shtompel M.A., Candidate of Techn. Sciences, docent of "Transport connection" Department, Ukrainian State University of Railway Transport, Kharkiv, Ukraine. 